\section{\{⿻ำ $\mathrm{HePG}$ \\ ISSN: 2348-1900

\title{
Impact of fast and slow desiccation on Garcinia imberti seed and seedling vigour
}

\author{
Anto $M$ and Anilkumar $C^{*}$ \\ Conservation Biology Division, Jawaharlal Nehru Tropical Botanic Garden and Research Institute, Palode, Thiruvananthapuram \\ 695562 India
}

\section{Article history}

Received: 14 May 2018

Accepted: 05 July 2018

Published: 06 July 2018

\section{Copyright}

(C) Anto \& Anilkumar (2018). This

is an open-access article

distributed under the terms of

the Creative Commons

Attribution License, which permits unrestricted use,

distribution, and reproduction in

any medium, provided the

original author and source are

credited.

\section{Editor}

K K Sabu, Jawaharlal Nehru Tropical Botanic Garden and Research Institute, India

\section{Publisher}

Horizon e-Publishing Group

\section{*Correspondence}

C. Anilkumar

$\Xi_{\text {canildeepa@yahoo.co.in }}$

\begin{abstract}
Garcinia imberti Bourd. endemic to the southern Western Ghats is classified as endangered by the IUCN (2018). The seeds as the sole means of propagation with initial moisture content (MC) of $62.8 \%$ are sensitive to desiccation. Studies on the responses of the seed to drying require ascertaining of the critical moisture content (CMC) as a basic requisite for germplasm conservation. Responses of $G$. imberti seeds to fast drying with activated silica gel $\left(25 \pm 2{ }^{\circ} \mathrm{C}, 6 \pm 1 \% \mathrm{RH}\right)$ and to slow drying under laboratory conditions $\left(28 \pm 2{ }^{\circ} \mathrm{C}, 60 \pm 2 \%\right.$ $\mathrm{RH})$ were evaluated for seed and seedling vigour. When the MC was reduced to $56 \%$ by 48 hours of slow drying or 6 hours of fast drying, 75 to $90 \%$ normal seedlings were produced respectively. In the case of fast dried seed (6 hours), seed associated parameters except mean germination time showed peak values with maximum germination and enhanced root length. Below the CMCs of 16.4 and $26.3 \%$ (fast and slow drying respectively), half of the tested seeds become non viable. Thus for germplasm conservation the present study proposes 6 hour's of fast drying to retain viability and normal seedling development of $G$. imberti.
\end{abstract}

\section{Keywords}

Agasthyamala Biosphere Reserve; Desiccation; Moisture content; Recalcitrant seed; Seed storage practises

\section{Citation}

Anto M, Anilkumar C. Impact of fast and slow desiccation on Garcinia imberti seed and seedling vigour. Plant Science Today 2018;5(3):95-102. https://dx.doi.org/10.14719/ pst.2018.5.3.398

\section{Introduction}

The Genus Garcinia L. of the family Clusiaceae comprising 400-600 tropical species (1) is an important component of Western Ghats flora. This genus has 9 species and 2 varieties indigenous to the Western Ghats and in particular 7 of the species and 2 varieties are endemic to the Agasthyamala Biosphere Reserve (ABR) (2). G. imberti is one of the endangered and endemic species to ABR (3) confined to an altitudinal range of $600-1200 \mathrm{msl}$ (4). The niche specificity of the species is related to this narrow distribution, recruitment failure due to high fruit/seed predation rate and an extended period of seed dormancy (5).

In general, Garcinia seed propagation is characterised by the peculiar 'Garcinia type' hypogeal germination (6) along with dormancy. Similar to the reported dormancy of G. gummigutta (7), G. imberti seeds germinate only after a period of 5-6 months due to the physical barrier of the seed coat (8). According to Normah et al. 
(9) all Garcinia species show dormancy, except G. mangostana. Most species of the genus Garcinia also shed their seeds at high moisture contents with low viability and desiccation sensitivity (10) and are thus considered to be recalcitrant. Recalcitrant seeds lose viability at relatively high moisture contents and their desiccation sensitivity imposes a severe problem for the long term conservation of many tropical plants' genetic resources $(11,12)$. Consequently the main challenge for the ex situ conservation of $G$. imberti is its sensitivity to drying of the seeds below a critical moisture content. This leads to quick loss of viability though the reduction of moisture content to a minimum safe level that reduce seed vigour and seed storability. The germination performance of $G$. imberti seeds subjected to desiccation has been studied in detail along with features of low flower to fruit ratio, poor natural regeneration and crucial fruit/seed predation. Ex situ conservation of plant species via seed is the most convenient and reliable method for gene banks and cryobanks (13-15). Studies on sensitivity to desiccation have been undertaken on many tropical and sub- tropical species to achieve germplasm storage and the present study has followed the responses of the seed of $G$. imberti to such an approach.

\section{Materials and Methods}

G. imberti fruits were harvested between September and November of 2015-2017 with 20 accessions each in the evergreen forests at

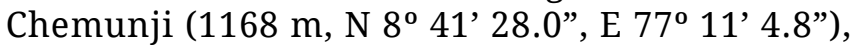
Bonacaud (943 m, N 8 $8^{\circ} 45^{\prime} 25^{\prime \prime}$, E $\left.77^{\circ} 11^{\prime} 20^{\prime \prime}\right)$ and Ponmudi (1003 m, N $8^{\circ} 45^{\prime} 50.2$, E $77^{\circ} 6^{\prime}$ 48.5”) located at altitudes ranging from 600 to $1200 \mathrm{msl}$ of southern Western Ghats. Fully ripened fruits were identified by their brilliant yellowish-green and fruits were directly collected from the mother trees. After harvesting, the fruits were brought to the laboratory and the outer coat removed by manual pressing. These seeds were thoroughly washed under running water and thereafter allowed to surface dry in laboratory conditions.

Seed desiccation effect on the loss of viability was studied by subjecting the seed to two different treatments (16): (a) seeds in open plastic trays were exposed to laboratory conditions (slow desiccation) $\left(28 \pm 2^{\circ} \mathrm{C}, 60 \pm 2 \%\right.$ RH) for 240 hours and at each 24 hour interval the water content was determined; (b) seeds in $4 \mathrm{~L}$ capacity desiccators containing $3 \mathrm{~kg}$ of activated silica gel (fast desiccation) $\left(25 \pm 2{ }^{\circ} \mathrm{C}, 6\right.$ $\pm 1 \% \mathrm{RH}$ ) were dried for 63 hours. The moisture content was determined every three hours. The silica gel was replaced as soon as it lost its indicative blue colour.

The following aspects were studied in order to assess impact of seed drying on physiological potentials:

\section{Moisture content}

For each drying method seed moisture content was determined using the high constant temperature oven method $\left(130 \pm 2^{\circ} \mathrm{C}\right.$ for two hours). Ten replicates of two seeds each were made and calculated on a fresh weight basis.

\section{Seed germination}

Germination tests were carried out with ten replicates of 10 desiccated and non-desiccated de-coated seeds each, rolled in an acid free moist germination paper kept in a seed germinator without light $\left(30 \pm 2^{\circ} \mathrm{C}, 80 \% \mathrm{RH}\right)$. The viability was checked on the basis of the germinated seed percentage. Seeds were scored as germinated when the radicle reach $5 \mathrm{~mm}$. Observations on germination were noted daily. The seed germination associated parameters of speed of germination (SPG), mean germination time (MGT) (17), mean daily germination (MDG), peak value (PV) and germination value (GV) (18) were calculated.

\section{Seedling length}

Seedling length was obtained by measuring the lengths of the root and shoots with five replicates of 10 seedlings (100 days old) each, using a millimetre ruler. The results were expressed in centimetres.

\section{Normal and abnormal seedlings}

Evaluations were performed 60 days after sowing by computing the percentages of normal seedlings, using the presence of well-developed shoots and root system as the criteria.

\section{Seed Vigour Index (SVI)}

After 100 days of drying SVI was calculated by multiplying germination percentage and seedling length (19) before planting in the field.

\section{Statistical analysis}

The data were statistically analysed by one-way ANOVA and values expressed as mean \pm standard error. Significance of differences 
between mean values was tested by least significant difference (LSD) $(P<0.05)$. Means followed by the same letter in the column do not differ significantly by Tukey's post hoc test of Honest Significant Difference.

\section{Results}

G. imberti seeds are the sole propagation agent with an initial moisture content of $62.8 \pm 0.15 \%$. Seeds showed a type of hypogeal germination and possess $1.2 \pm 0.2$ years of dormancy with only $38 \pm 1.3 \%$ of germination. During desiccation, both seed moisture content (MC) and germination percentage (GP) concurrently declined irrespective of the drying method indicating the recalcitrant nature of the seed. The drying method and duration significantly affected the level of seed moisture content and the final seed moisture content was higher when slowly dried at room temperature compared with fast drying with silica gel. In $G$. imberti, the fast drying method improved germination along with other seedling physiological characters in comparison with the slow drying. It took more than 240 hour to reach a moisture content of $17.68 \%$ with the slow drying method. Whereas when fast dried, it took only 48 hours to attain a moisture content of $17.75 \%$ (Fig. 1-a).

Fast dried seeds germinated earlier than those that had been slow dried implying that drying speed influenced physiological potential and level of damage sustained by the seeds. During fast drying, the MC of the seeds reduced quickly along with significant reductions in GP. In this regard at 51-54 ${ }^{\text {th }}$ hours of fast drying the germination percentage rapidly declined from 50.5 to $25.1 \%$ and consequently it is suggested that the MC at the $51^{\text {th }}$ hour is the critical moisture content of the species i.e., $16.4 \%$. For the slow dried seeds the significant germination drop from 43.0 to $25.8 \%$ was observed between $192-216^{\text {th }}$ hours indicating that the critical moisture content i.e., 26.33 \% (Fig. 1-h.) was reached at 192 hours of drying. The 6 hours of fast desiccated and 48 hours of slow desiccated seeds registered cent percent of germination (Fig. 1-c). All seed associated parameters except MGT showed peak values at 6 hour of fast desiccation while only PV and GV registered peak values at 48 hours of slow desiccation (Fig. 1-d).

The Pearson correlation coefficient of fast $\left(\mathrm{r}=0.94^{* *}\right)$ and slow $\left(\mathrm{r}=0.98^{* *}\right)$ desiccated seed associated parameters indicated that the MC and GP were positively correlated even though the MGT and GP were negatively correlated and significant at both 5 and $1 \%$ levels. MDG as the average number of seeds germinating per day of the definite test period showed positive correlation with GV which indexed combined speed and total germination. MGT of desiccated seeds displayed negative correlation with MC, GP, MDG, SPG, PV and GV in both drying methods (Fig.1b-g). The minimum safe MGT and maximum PV and GV were noted in the 24th hour of slow desiccation and the MGT and GP were negatively correlated $\left(\mathrm{r}=-0.802^{* *}\right)$ and significant at both levels. The fast $\left(\mathrm{r}=0.915^{* *}\right)$ and slow $\left(\mathrm{r}=0.923^{* *}\right)$ desiccated seeds showed positive correlation between PV and GV as an index that combines speed and total germination.

The root and shoot length were affected by slow and fast drying. With fast drying, the longest root value was $2.4 \mathrm{~cm}$ and shoot value was 3.46 $\mathrm{cm}$ attained after 6 hours of drying to reach a moisture content of $56.2 \%$. Whilst after slow drying, the seeds produced roots of variable length and it was observed that seeds dried for 192 hour produced longer roots $(2.9 \mathrm{~cm})$. The shoot length exhibited maximum i.e., $3.1 \mathrm{~cm}$ at 144 hours of slow desiccation, however it produced very low percentage of normal seedlings (Table 1). The physiological potential of seeds subjected to slow drying is more affected at lower levels of moisture.

Normal seedling production of $67.6 \%$ was enhanced to 75.0 and $92.5 \%$ upon to 48 hours of slow and 6 hours of fast desiccation respectively (Table 1). The employed desiccation methods exposed different levels of sensitivity of seeds to desiccation and the production of normal seedlings at the observed moisture content values. More than 50\% normal seedlings were produced at $50.6 \% \mathrm{MC}$ of slow drying and $40.2 \% \mathrm{MC}$ of fast drying respectively. Monitoring the rate of seed vigour index showed a decline in the vigour of the seeds during desiccation. The seeds subjected to fast drying had higher seed vigour index than those of seeds subjected to slow drying, indicating the damage caused by slow desiccation. This was proved with the comparative 6 hours fast and 48 hours of slow desiccation with seed vigour index i.e., 590 and 400 respectively (Table 1).

\section{Discussion}

G. imberti seeds, which are recalcitrant with 62.8 $\%$ initial moisture content, are the sole medium of propagation. The seeds of most Garcinia species are reported (20) as not true seeds which are devoid of endosperm/cotyledons and embryonic axis or any structure remotely similar to it. The recalcitrant seeds in general remain sensitive to desiccation throughout their development and have limited longevity, even in an environment with elevated moisture content (21). It was reported that, desiccation sensitive seeds are most common in tropical rainforests (22). The G. imberti seeds with hypogeal type of germination $(38 \pm 1.3 \%)$ by nature possess $1.2 \pm 0.2$ years of dormancy. Seed decoating was reported as the best method for 

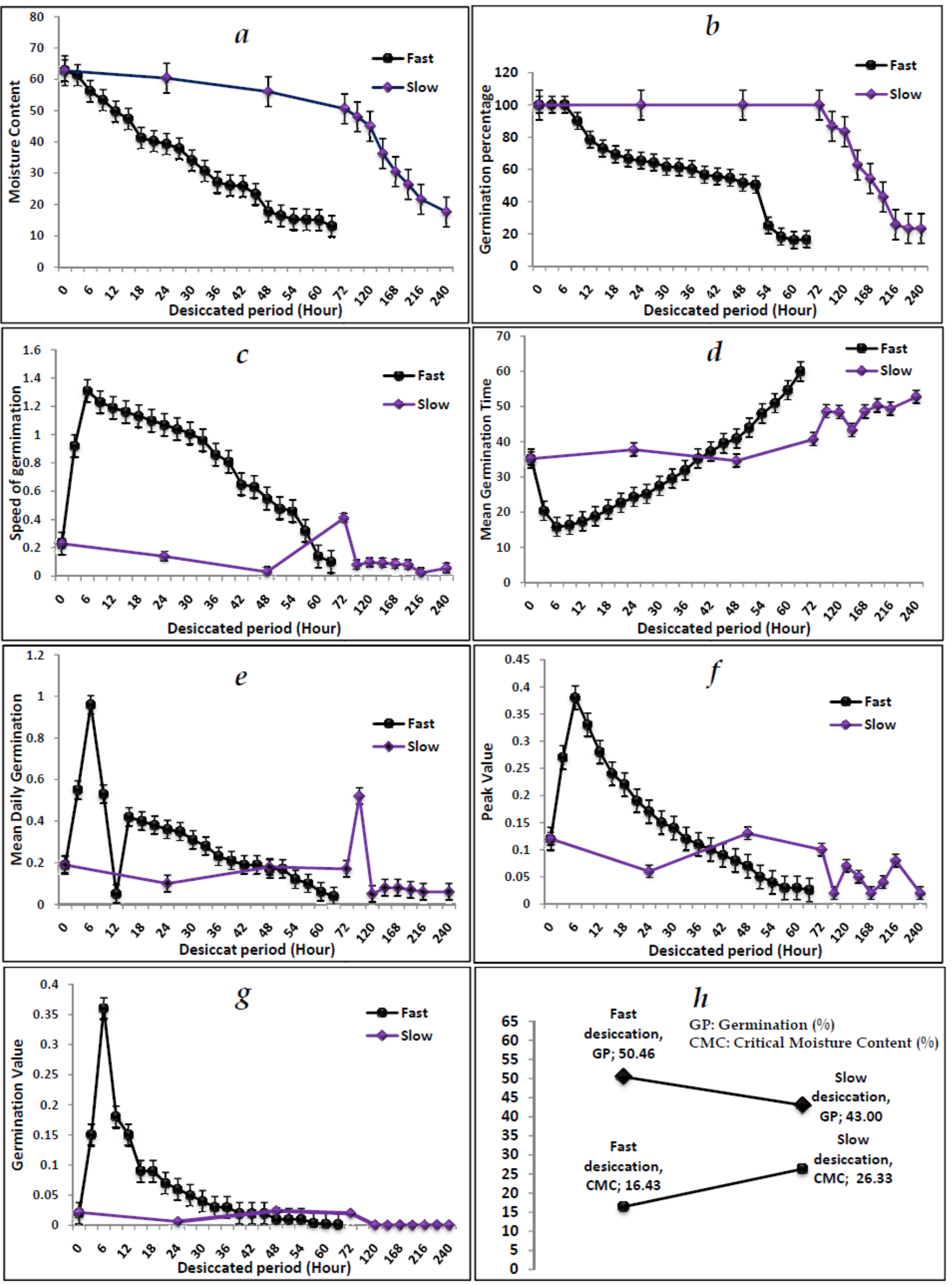

Fig. 1 a-h. Seed germination associated parameters of both fast and slow desiccated seeds

alleviating its physical dormancy in G. imberti (8). germination percentage became concurrently and When desiccated, both moisture content and significantly reduced irrespective of their 
Table 1. Assessment of adventitious root length, shoot length, seed vigour index and percentage of normal seedling of both fast and slow desiccated seeds $(n=10)$

\begin{tabular}{|c|c|c|c|c|c|c|c|c|}
\hline \multicolumn{5}{|c|}{$\begin{array}{l}\text { Period Adventurous root length (cm) Shoot length (cm) } \\
\text { (Hours) }\end{array}$} & \multicolumn{2}{|c|}{ Seed vigour index } & \multicolumn{2}{|c|}{ Normal seedling (\%) } \\
\hline & Fast & Slow & Fast & Slow & Fast & Slow & Fast & Slow \\
\hline$\overline{0}$ & $1.58 \pm 0.23^{j \mathrm{k}}$ & $1.58 \pm 0.2^{\mathrm{bcd}}$ & $2.40 \pm 0.22^{\mathrm{e}}$ & $2.04 \pm 0.2^{\mathrm{abc}}$ & $398.3 \pm 43.0^{\mathrm{i}}$ & $398.3 \pm 43.0^{c}$ & $67.60 \pm 1.01^{\mathrm{ij}}$ & $67.60 \pm 1.01^{\mathrm{d}}$ \\
\hline 6 & $2.43 \pm 0.16^{1}$ & & $3.46 \pm 0.18^{\mathrm{f}}$ & & $590.0 \pm 31.1^{j^{* *}}$ & & $92.50 \pm 1.05^{\mathrm{m}^{* *}}$ & \\
\hline 9 & $1.23 \pm 0.00^{\mathrm{ijk}}$ & & $2.88 \pm 0.15^{\mathrm{ef}}$ & & $369.9 \pm 14.1^{\mathrm{hi}}$ & & $87.66 \pm 0.4^{\mathrm{lm}^{* *}}$ & \\
\hline 12 & $1.18 \pm 0.01^{\mathrm{ij}}$ & & $2.55 \pm 0.41^{\mathrm{e}}$ & & $291.9 \pm 33.2^{\mathrm{gh}^{* *}}$ & & $75.33 \pm 0.84^{j \mathrm{k}}$ & \\
\hline 15 & $1.15 \pm 0.01^{\mathrm{ij}}$ & & $1.66 \pm 0.19^{\mathrm{cd}^{*}}$ & & $205.00 \pm 14.4^{\mathrm{fg} * *}$ & & $77.33 \pm 1.05^{\mathrm{k}^{*}}$ & \\
\hline 18 & $1.16 \pm 0.02^{\mathrm{ij}}$ & & $1.20 \pm 0.02^{\mathrm{bc} * *}$ & & $163.5 \pm 2.4^{\mathrm{e}^{\mathrm{f} *}}$ & & $62.66 \pm 1.64^{\mathrm{i}}$ & \\
\hline 21 & $1.09 \pm 0.01^{\mathrm{hi}^{*}}$ & & $1.18 \pm 0.01^{\mathrm{bc} * *}$ & & $150.7 \pm 1.9^{\mathrm{def}^{* *}}$ & & $62.00 \pm 1.50^{\mathrm{i}}$ & \\
\hline 24 & $1.07 \pm 0.01^{\text {ghi* }^{*}}$ & $1.52 \pm 0.3^{\mathrm{bcd}}$ & $1.14 \pm 0.01^{\mathrm{bc} * *}$ & $2.48 \pm 0.2^{\mathrm{bc}}$ & $145.7 \pm 1.8^{\operatorname{def}^{* *}}$ & $402.0 \pm 41.3^{c}$ & $53.3 \pm 3.23^{\mathrm{h}^{* *}}$ & $51.40 \pm 0.50^{\mathrm{c}^{* *}}$ \\
\hline 27 & $1.04 \pm 0.01^{\text {ghi* }^{*}}$ & & $1.14 \pm 0.03^{\mathrm{bc} * *}$ & & $139.3 \pm 2.1^{\text {cdef** }^{* *}}$ & & $36.33 \pm 5.4^{\mathrm{gh}^{* *}}$ & \\
\hline 30 & $0.99 \pm 0.02^{\text {fghi* }^{* *}}$ & & $1.05 \pm 0.03^{\mathrm{abc} * *}$ & & $124.3 \pm 2.8^{\text {cdef }^{* *}}$ & & $31.66 \pm 0.6^{\mathrm{fg} * *}$ & \\
\hline 33 & $0.94 \pm 0.04^{\mathrm{efghi}^{* *}}$ & & $1.04 \pm 0.02^{\mathrm{abc} * *}$ & & $120.8 \pm 3.4^{\text {cdef** }^{* *}}$ & & $25.66 \pm 0.9^{\mathrm{e}^{\mathrm{e} * *}}$ & \\
\hline 36 & $0.87 \pm 0.01^{\text {defghi }^{* *}}$ & & $0.99 \pm 0.04^{\mathrm{abc}^{* *}}$ & & $111.5 \pm 2.7^{\text {bcde }^{* *}}$ & & $25.66 \pm 2.2^{\mathrm{e}^{* * *}}$ & \\
\hline 39 & $0.76 \pm 0.05^{\text {cdefghi** }}$ & & $0.96 \pm 0.03^{\mathrm{abc} c^{* *}}$ & & $96.8 \pm 4.1^{\mathrm{abcde}^{* *}}$ & & $23.83 \pm 0.4^{\text {cdef** }^{* *}}$ & \\
\hline 45 & $0.61 \pm 0.02^{\text {bcdefgh } * *}$ & & $0.84 \pm 0.02^{a b^{* *}}$ & & $78.5 \pm 1.6^{\text {abcde }^{* *}}$ & & $15.33 \pm 1.9^{\mathrm{abcd}^{* *}}$ & \\
\hline 48 & $0.52 \pm 0.03^{\text {abcdef** }}$ & $1.26 \pm 0.33^{\mathrm{bc}}$ & $0.72 \pm 0.05^{\mathrm{ab}^{* *}}$ & $2.10 \pm 0.2^{\mathrm{abc}}$ & $68.2 \pm 6.8^{\mathrm{abcd}{ }^{* *}}$ & $336.0 \pm 27.6^{c}$ & $22.00 \pm 2.4^{\text {bcdef }^{* *}}$ & $75.00 \pm 1.41^{\mathrm{d}}$ \\
\hline 51 & $0.48 \pm 0.02^{\text {abcde }^{* *}}$ & & $0.57 \pm 0.05^{\mathrm{ab} \mathrm{b}^{* *}}$ & & $53.2 \pm 2.9^{\mathrm{abc}^{* *}}$ & & $13.16 \pm 1.60^{a b^{* *}}$ & \\
\hline 54 & $0.45 \pm 0.02^{\mathrm{abcd} * *}$ & & $0.58 \pm 0.02^{\mathrm{ab}{ }^{* *}}$ & & $25.3 \pm 0.8^{\mathrm{ab}^{* *}}$ & & $10.50 \pm 0.34^{\mathrm{a}^{* *}}$ & \\
\hline 57 & $0.29 \pm 0.02^{\mathrm{abc} * *}$ & & $0.51 \pm 0.02^{\mathrm{ab}^{* *}}$ & & $14.3 \pm 0.9^{\mathrm{a}^{* *}}$ & & $17.66 \pm 1.2^{\text {abcde }^{* *}}$ & \\
\hline 60 & $0.19 \pm 0.06^{\mathrm{ab}^{* *}}$ & & $0.49 \pm 0.02^{\mathrm{ab}^{* *}}$ & & $10.7 \pm 1.2^{\mathrm{a}^{* *}}$ & & $13.83 \pm 1.8^{\mathrm{abc}^{* *}}$ & \\
\hline 63 & $0.09 \pm 0.01^{\mathrm{a}^{* *}}$ & & $0.40 \pm 0.04^{\mathrm{a}^{* *}}$ & & $07.7 \pm 0.8^{\mathrm{a}^{* *}}$ & & $07.66 \pm 0.49^{\mathrm{a}^{* *}}$ & \\
\hline 72 & & $1.42 \pm 0.32^{\mathrm{bc}}$ & & $2.28 \pm 0.3^{\mathrm{abc}}$ & & $370.0 \pm 44.9^{c}$ & & $57.00 \pm 1.70^{\mathrm{c}^{*}}$ \\
\hline 96 & & $1.98 \pm 0.2^{\text {cde }}$ & & $2.32 \pm 0.4^{\mathrm{abc}}$ & & $371.4 \pm 38.1^{\mathrm{c}}$ & & $30.40 \pm 2.11^{\mathrm{a}^{* *}}$ \\
\hline 120 & & $2.26 \pm 0.1^{\mathrm{def}}$ & & $2.60 \pm 0.1^{\mathrm{bc}}$ & & $401.4 \pm 22.7^{c}$ & & $27.80 \pm 1.95^{a^{* *}}$ \\
\hline 144 & & $2.66 \pm 0.2^{\mathrm{ef}^{* *}}$ & & $3.08 \pm 0.4^{\mathrm{c}}$ & & $358.8 \pm 34.5^{c}$ & & $40.60 \pm 1.50^{\mathrm{b}^{* *}}$ \\
\hline 168 & & $1.20 \pm 0.38^{\mathrm{bc}}$ & & $1.82 \pm 0.5^{\mathrm{abc}}$ & & $160.1 \pm 23.4^{\mathrm{b}^{* *}}$ & & $21.20 \pm 2.05^{a^{* *}}$ \\
\hline 192 & & $2.86 \pm 0.14^{\mathrm{f**}}$ & & $2.14 \pm 0.1^{\mathrm{abc}}$ & & $216.0 \pm 18.3^{\mathrm{b}^{* *}}$ & & $49.40 \pm 2.80^{\mathrm{bc}^{* *}}$ \\
\hline 216 & & $0.34 \pm 0.1^{\mathrm{a}^{* *}}$ & & $1.54 \pm 0.3^{\mathrm{ab}}$ & & $46.2 \pm 6.6^{\mathrm{a}^{* *}}$ & & $22.20 \pm 2.31^{\mathrm{a}^{* *}}$ \\
\hline 240 & & $1.06 \pm 0.26^{\mathrm{b}}$ & & $1.00 \pm 0.1^{\mathrm{a}}$ & & $59.6 \pm 6.1^{\mathrm{a}^{* *}}$ & & $20.60 \pm 1.80^{\mathrm{a}^{* *}}$ \\
\hline
\end{tabular}

desiccation methods that indicated recalcitrance nature of the seed. One of the factors affecting sensitivity to desiccation is the drying rate and also depends on innate seed properties such as the nature of the seed coat, size, and developmental stage (11).

The consequence of desiccation method and duration of germination were significant and depend on the species and its final moisture content (23). However in $G$. imberti, the fast desiccation method improved germination and seedling vigour in comparison to slow desiccation. Thus, fast drying was less adverse than slow drying, probably due to the embryo like structure being safe guarded from too much drying. It was reported that the mechanisms by which the fast drying of recalcitrant seeds confer greater tolerance to lower water content have yet to be explained (24). It has been suggested that the metabolic functions of cells are distorted in seeds with moisture content in-between that of the fully hydrated state and the lower threshold of tolerance for a longer period as in the case of slow desiccation (25). Thus the fast desiccated seeds were exposed to intermediate levels of hydration only for a brief period which in turn curtailed the probable injury associated with desiccation (26).

Water as a protectant of macromolecular structure controls the level of metabolic activity in plants and in fact the germination potential of a seed is directly correlated with the tolerable moisture content. In G. imberti, the critical moisture content significantly varies with respective germination percentage in accordance with the fast and slow drying methods adopted. It was stated that differential responses to desiccation at different drying rates denote difficulty to define a single critical moisture content value for recalcitrant seeds (27). Hence, desiccation to 16.4 and $26.3 \%$ moisture content levels at fast and slow drying respectively may be considered as two different critical moisture contents of $G$. imberti. Effect of fast and slow desiccation on Saraca asoca seeds with respect to different critical moisture contents i.e., 36.3 and $46.9 \%$ values were reported earlier (28). During fast desiccation, the peripheral $G$. imberti seed cells may dry fast unlike the embryo- like structure that may provide safe water physiology favouring extended seed viability. On continued desiccation, the moisture content of the G. imberti seeds was reduced further along with significant reduction of germination percentage. The reduction of water strongly affects the nature of physical and biochemical reactions (29). Alterations in cell membranes were the main structural damage associated with seed desiccation (30) and due to these types of irreversible damages, seeds suffer from reduced germination and vigour or even loss of viability (31). The $G$. imberti seeds registered significant loss of viability below $16 \%$ moisture 
Seed germination associated parameters are important factors in seed biology and it varied with methods of seed drying. In G. imberti, mean germination time of the both fast and slow desiccated seeds displayed negative correlation with moisture content, germination percentage, mean daily germination, speed of germination, peak value and germination value. A similar observation was noted in desiccated $S$. asoca seeds in which both leachate conductivity and MGT displayed negative correlation with MC, GP, MDG, SPG, PV and GV (28). Mean germination time of $G$. imberti seeds gradually increased during both methods of desiccation which is linked to seed vigour loss. It was pointed out that irrespective of the desiccation method adopted, the inverse proportionality between MDG and MGT values signifies the adverse effect of deterioration on S. asoca seeds during desiccation (28). Slower water absorption capacity and smaller surface area to mass ratio (34) were the possible factors of longer MGT in large seeded species (35). All seed associated parameters except MGT showed the peak value significant at both 5 and $1 \%$ levels at 6 hour in fast desiccated $G$. imberti seeds as an indication of seed vigour. The maximum MGT of slow desiccated seeds noted in the 240 hour of desiccation indicated damage due to drying of seeds. One of the first indication of seed ageing was an enhanced MGT as reported earlier (36).

In dried G. imberti seeds, though MDG was decreased, increased MGT showed the adverse effect of vigour deterioration during desiccation. Hence, the Pearson correlation coefficient of seed associated parameters indicated that the MGT and GP are negatively correlated and significant with both of the desiccation methods in G. imberti. It was reported that the drying rate affected not only the Genipaa mericana seed germination percentage, but also the germination associated parameters especially speed of germination (37). Germination aspects like SPG, PV, MDG and GV were high in seeds with high MC, while they were dropped considerably during desiccation. The 24 hours of fast and slow desiccated seeds showed that, the GP, SPG, MDG, PV, GV and percentage of normal seedlings were highest in fast desiccated seeds; however the seed vigour index was higher in slow desiccated seeds. Nevertheless with respect to seed desiccation and germplasm storage practices, the 24 hours of slow desiccation in seeds with more water content may not support extended seed storage. The slow drying contributed homogeneous dehydration and seed tissues spend a prolonged period at intermediary water contents which leads to extensive membrane damages $(29,30)$. It was also observed that $G$. imberti when subjected to 72 hours of slow drying beyond the proposed optimum period of 48 hours slow drying with $56 \%$ moisture content, the germination percentage remained unaltered, but seedling vigour parameters were observed to be deteriorated. It was pointed out the fact that, membranes are particularly susceptible to damage during slow desiccation, because the degradative process emerges to be aqueous based and oxidative in nature (27).

The GV and PV were correlated, because the parameter of PV influenced the value of GV. Most of desiccation treatments in $G$. imberti followed the correlation between PV and GV and were linked. GV was an index of combining seed germination and its speed (18) which was closely linked to Pinus ponderosa seedling survival (39).

The root and shoot length of $G$. imberti seedlings were negatively affected by both desiccation methods. Corroborating the statement by Martins et al. (38) the seedling growth rate as expressed by length of plumule and radicle was significantly reduced for Archonto phoenix alexandrae seeds with lower moisture content (below 28.2\%) than seeds at optimum levels (47.5$34.6 \%)$. At 6 th hour of fast desiccated G. imberti seeds, the highest root length of 2.43 and shoot length of $3.46 \mathrm{~cm}$ were attained at higher moisture content, and it gradually decreased to lower moisture content because it ruptured the viable cells during dehydration. In $G$. imberti seeds 6 hours of fast desiccation lowered MC from 62.8 to $56.2 \%$ with $100 \%$ germination and an enhanced root length compared to non desiccated seeds (5). Dresch et al. (40) pointed out that the shoot length was negatively affected by fast desiccation at low moisture content in Campomanesia adamantium seeds.

After slow drying, the highest root length $\mathrm{i}$. e., $2.9 \mathrm{~cm}$ and shoot length i. e., $3.1 \mathrm{~cm}$ were attained at reduced MC, however it produce only very less percentage of normal seedlings. A reduction in the root length was noted in seeds of Hancornia speciosa (41), and Eugenia pyriformis (42) after desiccation. The maximum seed vigour index i.e., 590 (6th hour) and 402 (24th hour) of both fast and slow desiccated seeds respectively and below the critical moisture content, seeds exhibited less $G$. imberti germination percentage and seed vigour index. The seedling length and seed vigour index of $G$. imberti were also reduced during continuous desiccation. It was reported that, the whole plant length was negatively affected by the rate of dehydration of the Campomanesia xanthocarpa seeds that delayed seedling growth (43).

The percentage of abnormal seedling of $G$. imberti as higher in the intermediary moisture levels (17.6\% to $45.02 \%)$. Many authors (44-46) stated that, seeds dried at intermediate moisture content could endure harmful aqueous based reactions, leading to reduced germination percentage and increased abnormal seedlings. The employed desiccation methods exhibited different levels of sensitivity of $G$. imberti seeds to desiccation and the production of normal seedlings at the observed moisture content values. Similar observation revealed the occurrence 
of normal seedlings of Campomanesia adamantium favoured by the seed drying methods and decreased linearly with the MC (40). More than 50\% normal seedlings of $G$. imberti were produced at $40.2 \%$ moisture content of fast and $50.6 \%$ moisture content of slow desiccation respectively. According to a previous study (40), the seeds of $C$. adamantium produced $56 \%$ of normal seedlings at $21.1 \%$ of moisture content after fast and $17.2 \%$ of moisture content after slow desiccation respectively. The highest percentage of normal seedling i.e., 92.5 (6th hour) and $75 \%$ (48th hour) were produced both fast and slow desiccated seeds respectively indicated the vigour of the G. imberti seeds. It was point out that, fast dried Citrus reshni seeds were more advantageous and it provided more root protrusion along with lower percentage of abnormal seedlings (47). In G. imberti, seeds at less moisture content registered more seed vigour index and produced a higher percentage of normal seedlings. The study reported a similar observation that, $C$. reshni seeds dried from $46 \%$ (fresh) to $25 \%$ moisture content had a higher percentage of normal seedling compared to the fresh seeds (47).To conclude with, 6 hours of fast desiccation was found to be optimal for cent percentage Garcinia imberti seed germination and seedlings with maximum vigour.

\section{Acknowledgements}

The authors greatly acknowledge the Director, JNTBGRI for facilities provided and SERB, Department of Science and Technology (DST), Government of India for financial support. The Authors express sincere thanks to the Kerala University for approved Ph.D. programme on Garcinia imberti Bourd.

\section{Conflict of Interest}

There is no conflict of interest among the authors.

\section{Author's contributions}

Both authors contributed equally to carry out the research and prepare the article.

\section{References}

1. Asomaning J M, Olympio N S, Sacande M. Desiccation sensitivity and germination of recalcitrant Garcinia kola Heckel Seeds. Research Journal of Seed Science 2011; 4: 15-27.

2. Shameer P S, Rameshkumar K B, Mohanan N. Diversity of Garcinia species in the Western Ghats. In Diversity of Garcinia species in the Western Ghats: Phytochemical Perspective. (ed. K. B., Rameshkumar) Jawaharlal Nehru Tropical Botanic Garden and Research Institute Palode, Thiruvananthapuram, Kerala, India. pp-01-18; 2016

3. The IUCN Red List of Threatened Species. Version 20173. <www.iucnredlist.org>. Downloaded on 19 February 2018.
4. Mohanan N, Shaju T, Rajkumar G, Pandurangan A G. Rediscovery of Garcinia imberti Bourd. Indian Journal of Forestry 1997; 20: 383-385.

5. Anto M, Anilkumar C. Fast desiccation response of seeds of Garcinia imberti Bourd. an endangered and endemic species to Agasthyamala Biosphere Reserve. Main streaming Biodiversity for sustainable development, Kerala State Biodiversity Board 2017; ISBN No. 978-81-934231-1-0, P-408-415.

6. de Vogel E F. Seedling of Dicotyledons: Structure, development, types; Description of 150 woody Malaysian taxa. (Centre for Agricultural Publishing and Documentation (PUDOC), Wageningen1980.

7. Anilkumar C, Babu K P, Krishnan P N. Dormancy mechanism and effects of treatments on the germination of Garcinia gummi-gutta (Clusiaceae) seeds. Journal of Tropical Forest Science 2002; 14: 322328.

8. Anilkumar C, Prajith T M, Jothish P S, Chitra C R, Ashraf A. Seed germination behavior of Garcinia imberti Bourd. The Indian Forester 2016; 142: 196-899.

9. Normah M N, Ramiya S D, Gintangga M. Desiccation sensitivity of recalcitrant seeds- a study on tropical fruit species. Seed Science Research 1997;7: 179-183.

10. Chacko K C, Pillai P K C. Seed characteristics and germination of Garcinia gummi-guta (L.) Robs. Indian Forester 1997; 123: 123-126.

11. Berjak P, Pammenter N W. From Avicennia to Zizania: Seed recalcitrance in perspective. Annals of Botany 2008; 101: 213-228.

12. Castro L E, Guimaraes C C, Faria J M R. Physiological, cellular and molecular aspects of the desiccation tolerance in Anadenanthera colubrina seeds during germination. Brazilian Journal of Biology 2017; 77: 774780.

13. Roberts E H. Predicting the storage life of seeds. Seed Science and Technology 1973; 1; 499-514.

14. Hong $\mathrm{T}$ D, Ellis R H. A protocol to determine Seed Storage Behaviour. IPGRI Technical Bulletin No. 1 (eds. J M M Engels and J Toll) International Plant Genetic Resources Institute, Rome, Italy; 1996.

15. Engelmann F. Importance of desiccation for the cryopreservation of recalcitrant seed and vegetatively propagated species. FAO/IPGRI Plant Genetic Resources Newsletter 1997; 112: 9-18.

16. Dayal B R, Kaveriappa K M. Effect of desiccation and temperature on germination and vigour of the seeds of Hopea parviflora Beddome and $H$. ponga (Dennst.) Mabb. Seed Science and Technology 2000; 28: 497-506.

17. Ellis R H, Roberts E H. The quantification of ageing and survival in orthodox seeds. Seed Science and Technology 1981; 9: 373-409.

18. Czabator F J. Germination value: an index combining speed and completeness of pine seed germination. Forest Science 1962; 8:386- 395.

19. Abdul-Baki A A, Anderson J D. Vigor determination in soybean by multiple criteria. Crop Science 1973; 10:3134.

20. Malik S K, Chaudhury R. Abraham Z. Seed morphology and germination characteristics in three Garcinia species. Seed Science and Technology 2005; 33:595-604. 
21. Pammenter $\mathrm{N}$ W, Berjak P. Some thoughts on the evolution and ecology of recalcitrant seeds. Plant Species Biology 2000; 15: 153-156.

22. Tweddle J C, Dickie J B, Baskin C C, Baskin J M. Ecological aspects of seed desiccation sensitivity. Journal of Ecology 2003; 91: 294 - 304.

23. Yao X, Goodale U M, Li Z L, Huang Y, Wang X F, Cheng F Y, Tan Y H, Xiao C F, Lan Q Y. Relative importance of seed drying rate, desiccation Tolerance, and cryotolerance for the conservation of Ardisia elliptica, $A$. brunnescens and $A$. virens. Cryo letters 2014;35: 16270.

24. Berjak P, Pammenter N W. Implications of the lack of desiccation tolerance in recalcitrant seeds. Frontiers in Plant Science 2013; 4: 1-9.

25. Walters C, Pammenter N W, Berjak P, Crane J. Desiccation damage, accelerated ageing and respiration in desiccation tolerant and sensitive seeds. Seed Science Research 2001; 11: 135 - 148.

26. Wesley - Smith J, Pammenter N W, Berjak P, Walters C. The effects of two drying rates on the desiccation tolerance of embryonic axes of recalcitrant jackfruit (Artocarpus heterophyllus Lamk.) seeds. Annals of Botany 2001; 88: 653 - 664.

27. Pammenter N W, Greggains V, Kioko J I, Wesley-Smith J, Berjak P, Finch-Savage W E. Effects of differential drying rates on viability retention of recalcitrant seeds of Ekebergia capensis. Seed Science Research 1998; 8: 463-471.

28. Prajith T M, Anilkumar C. Seed desiccation responses in Saraca asoca (Roxb.) W. J. de Wilde. Current Science 2017; 112: 2462-2466.

29. Vertucci C W, Farrant J M. Acquisition and loss of desiccation tolerance. In Seed development and germination (eds, J Kigel and G Galili). pp. 237 - 271, New York, Marcel Dekker Inc.; 1995.

30. Senaratna T, McKersie B D. Loss of desiccation tolerance during seed germination: a free radical mechanism of injury. In Membranes, Metabolism and Dry Organisms, (ed. A C Leopold. pp. 85-101, Cornell University, Ithaca; 1986.

31. Bewley J D, Black M. Development- regulation and maturation. In Seeds; Physiology of Development and Germination (eds. J D Benley and M Black). pp. 117-145, 2nd ed., Plenun press, New York; 1994.

32. Malik S, Chaudhury R, Abraham Z. Desiccation Freezing sensitivity and longevity in seeds of Garcinia indica, G. cambogia and G. xanthochymus. Seed Science and Technology 2005; 33: 723-732.

33. Ellis R H. The longevity of seeds. Horticultural Science 1991;. 26: 1119 - 1125

34. Kikuzawa K, Koyama $H$, Scaling of soil water absorption by seeds: an experiment using seed analogues. Seed Science Research 1999; 9: 171 - 178.

35. Vazquez-Yanes C, Orozco-Segovia A. Patterns of seed longevity and germination in the tropical rain forest. Annual Review of Ecology, Evolution, and Systematics 1993;24: 69-87.

36. Matthews S, KhajehHosseini M. Length of the lag period of germination and metabolic repair explain vigour differences in seed lots of maize (Zea mays). Seed Science and Technology 2007; 35: 200 - 212.

37. Magistrali P R, Jose A C, Faria J M R, Nascimento J F. Slow drying outperforms rapid drying in augmenting the desiccation tolerance of Genipa americana seeds. Seed Science and Technology 2015; 43: 101-110.

38. Martins C C, Bovi M L A, Nakagava J. Desiccation effects on germination and vigor of King palm seeds. Horticultura Brasileira 2003; 21: 88-92.

39. Djavanshir K, Pourbeik H. Germination value: a new formula. Silvae Genetica 1976; 25: 79 - 83.

40. Dresch D M, Masetto T E, Scalon S P Q. Campomanesia adamantium (Cambess.) O. Berg seed desiccation: influence on vigor and nucleic acids, Annals of the Brazilian Academy of Sciences 2015;87: 2217-2228 http://dx.doi.org/10.1590/0001-3765201520140539.

41. Santos P C G, Alves E U, Guedes R S, Silva K B, De Almeida C E, De Lima C R, Quality of Hancornia speciosa Gomes seeds in function of drying periods. Semina: Agrarian Sciences 2010; 31: 343-352. http://dx.doi.org/10.5433/1679-0359.2010v31n2p343.

42. Scalon S P Q, Neves E M S, Masetto T E, Pereira Z V. Sensibilidade à dessecação e aoarmazenamentoemsementes de Eugenia pyriformis Cambess. (uvaia). [Desiccation sensivity and storage in Eugenia pyriformis Cambess. seeds (uvaia)]. Revista Brasileira de Fruticultura 2012; 34: 269-276.

43. Nunes D P, Dresch D M, Scalon S P Q, Pereira Z V. Drying and reduction in sensitivity to desiccation of Campomanesia xanthocarpa seeds, African Journal of Agricultural Research 2015;10: 2859-2865. http://dx.doi.org/10.5897/AJAR2015.9963.

44. Pammenter $\mathrm{N}$ W, Verticci $\mathrm{C}$ W, Berjak $\mathrm{P}$. Homeohydrous (recalcitrant) seeds: dehydration, the state of water and viability characteristics in Landolphia kirkii. Plant Physiology 1991; 96: 1093-1098.

45. Pritchard $\mathrm{H}$ W. Water potential and embryonic axis viability in recalcitrant seeds of Quercus rubra. Annals of Botany 1991; 67: 43-49.

46. Berjak P, Pammenter N W Possible mechanisms underlying the differing dehydration responses in recalcitrant and orthodox seeds: desiccation-associated sub cellular changes in propagules of Avicennia marina. Seed Science and Technology 1997; 12: 365-384.

47. Goncalves M L F, Faria J M R, Jose A C, Tonetti O A O, Marques E R. Desiccation tolerance and antioxidant enzymatic activity in Citrus reshni seeds exposed to various drying rates. Seed Science and Technology 2017; 45: 411-427. 